\title{
Polarization(s) in Labour Markets: Synthesis and Perspectives
}

\section{Alan Manning}

\section{(2) OpenEdition \\ 1 Journals}

\section{Electronic version}

URL: http://journals.openedition.org/travailemploi/8921

DOI: 10.4000/travailemploi.8921

ISSN: 1775-416X

\section{Publisher}

DARES - Ministère du Travail

\section{Printed version}

Date of publication: 1 January 2019

Number of pages: 13-24

ISSN: 0224-4365

\section{Electronic reference}

Alan Manning, «Polarization(s) in Labour Markets: Synthesis and Perspectives », Travail et Emploi [Online], 157 | 2019, Online since 01 January 2019, connection on 11 October 2019. URL : http:// journals.openedition.org/travailemploi/8921 ; DOI : 10.4000/travailemploi.8921 


\title{
Polarization(s) in Labour Markets: Synthesis and Perspectives*
}

\author{
Alan Manning ${ }^{* *}$
}

Dolarization is now well established and documented. The increase in the share of Phigh-wage and low-wage jobs at the expense of "intermediate" jobs has led to a polarization of jobs in the US (AUTOR, 2010; AUTOR, DORN, 2013; AUTOR et al., 2006). One can largely explain this by the automation of routine tasks that then disappear in favour of non-routine manual or intellectual tasks. The automation of tasks has also contributed to polarization of employment in Europe (Goos et al., 2009). Now there is a lot of concern in what the future holds for the world of work (e.g. ForD, 2015) and there are some important unanswered questions.

The first question is about whether polarization represents a fundamental change in the nature of technology and the way it affects the labour market, or whether it is a continuation of past trends. Technological change has caused huge changes on labour markets for decades, machines replacing what people could do. Does the appearance of information and computer technologies (ICT), artificial intelligence and robots make some difference compared to past trends? Is the pace of change faster than it used to be or not?

Another question is to know what polarization means for inequality, what it means for individuals. Evidence for polarization in employment shares is easy to find, but this is not the case for wage inequality since relative wage movements are small. This suggests the supply of labour to occupations is very elastic, and reallocation of labour can be achieved with small changes in flows of people into and out of occupations thanks to the fluidity across occupations. However, there are groups such as older workers for whom the impact of technology may be particularly bad. The question is then to know how individuals experience the process of polarization.

Polarization seems also to be related to globalisation, due to international reallocation of factors of production. An important question, not well-documented, is how globalisation affects polarization. Does the share of middle-skilled jobs increase in low and/or middle income countries or do these countries also experience polarization of their labour market?

\footnotetext{
* This text is based on the transcription of the speech given by Alan Manning at the international conference on "Polarization(s) in Labour Markets", held in Paris on 19 June 2018.

** Centre for Economic Performance, LSE; A.Manning@1se.ac.uk.
} 
Most of the empirical studies on polarization tend to compare outcomes across occupations, sectors or firms that are more or less affected by the automation of tasks. Those studies cannot assess the aggregate effect of these changes. The question is then: how can we assess the overall impact of polarization on the labour market? I will present some theory suggesting that in a general equilibrium framework the long run effects of technology should be positive for wages of workers on average. In this framework, new technology cannot make all types of workers worse off. This is due to a perfectly elastic supply of labour of different types in different occupations, and labour being ultimately the fixed factor in the long run.

In this text, I will express the view that polarization is mostly a continuation of past changes rather than something radically new, that it has often not had big implications for inequality because of relatively easy mobility across occupations and that there are reasons why new technology, of any form, is likely to lead to higher wages for most workers. But, there are no grounds for complacency. There is no reason to think that a market economy will deliver the efficient level of growth and there needs to be an active state to ensure that all benefit from growth.

\section{Polarization: Change or Continuity?}

BARANY, SIEGEL (2018) argue that some aspects of polarization go back decades, before they attracted much attention from mainstream economists. The replacement of craft workers in manufacturing, which can be seen as machines replacing a stereotypical middling job, started long before the arrival of computers and ICT. On the other hand, the replacement of clerical workers, also a middling type of job, is more recent and more connected to ICT. If some elements of polarization are newer than the others, the driving force of polarization is routinisation or automation. Machines have been replacing labour in jobs that can be routinised. Those jobs have tended to be, in recent decades, in the middle of the job or the wage distribution, which has led to a job polarization. However, there's a lot of heterogeneity in these jobs and uncertainty about future evolution.

The replacement of workers by the machine has fed many fears, the most recent of which concern the impact of artificial intelligence and robots. In 2013, FREY and OSBORNE examined the extent to which jobs are subject to computerisation (FREY, OSBORNE, 2017). They estimated the probability of computerisation for a large number of occupations and, based on these estimates, predicted the expected impacts of future computerisation on US labour market outcomes. According to their estimates, about 47 percent of total US employment was at risk. These estimates of the probability of automation were over an unspecified number of years, though they suggested a decade or two. 
It has been now six years since FREY and OSBORNE came up with their projections, about a quarter of the way through the two decades they talked about as a reasonable time horizon, and we can now have a look at what has happened in those five years. We reproduce in Table 1 the results of very simple occupations regressions from the US Occupational Employment Survey that provides data on employment and earnings for more than 700 occupations.

TABLE 1 - Change in Employment, 2012-2017

\begin{tabular}{lcc}
\hline Dependent Variable & Change Log Employment & Change Log Employment \\
Sample Period & $2012-2017$ & $2012-2017$ \\
\hline & Unweighted & Weighted \\
Probability of Automation & -0.018 & -0.015 \\
& $(0.004)$ & $(0.003)$ \\
$R^{2}$ & 0.016 & 0.015 \\
\hline
\end{tabular}

Source: US Occupational Employment Survey, author's calculations.

With a very simple regression of the change in each occupation log-employment on their estimated probability of automation from 2012 to 2017 (the last data FREY and OSBORNE had when they made the projection was 2012), we get a significant and negative effect (Table 1). The jobs with a higher probability of automation according to their estimate do have a slower employment growth or even employment has fallen over the last five years. But the explanatory power of this variable is incredibly low (the r-squared is 0.016) and the effect is not really very big, implying a difference of 20 percentage points over a period of 10 years between one job with zero probability of automation and another with a probability of 1 . For context, the actual changes at the 10th percentile is minus $22 \%$, the 90 th percentile is $+53 \%$. So, this is actually not predicting any Armageddon but it does seem to have some explanatory power for what happened after their projections. However, it remains possible that these results indicate only the beginning of the trend and that the phenomenon may accelerate. But if we take the 10 years prior to when FREY and OSBORNE made their prediction and see how well their estimated probability of automation predicts employment changes over that period, it actually turns out that is a much better predictor of employment change in the earlier years than it is in recent years (Table 2). It is not actually very surprising because the underlying task variables used to the routinisation measure are actually quite similar to those used to explain earlier technical change.

Another thing that may seem surprising is that if we look at the change in logwages over the five-year period following the FREY and OSBORNE's prediction, there is basically no relationship. If there is any relationship, it actually goes in the opposite direction. Thus, the most automatable jobs have faster wage growth, which is rather surprising. 
TABLE 2 - Change in Employment and Wages, Different Sample Periods

\begin{tabular}{lccc}
\hline Dependent Variable & Change Log Employment & Change Log Employment & Change in Log Wages \\
Sample Period & $2000-2011$ & $2000-2004$ & $2012-2017$ \\
\hline Probability of Automation & -0.036 & -0.033 & 0.003 \\
& $(0.004)$ & $(0.006)$ & $(0.001)$ \\
$R^{2}$ & 0.069 & 0.026 & 0.067 \\
\hline
\end{tabular}

Source: US Occupational Employment Survey, author's calculations.

This evidence suggests that polarization is more likely a continuation of existing trends than a radical break with the past.

\section{Polarization and Inequality}

A number of papers presented during the conference have mentioned that it is much easier to find evidence for polarization in changes in employment shares than in wage inequality itself. Some occupations can decline in size by 90,95 percent; others grow by hundreds of percent. But movements in relative wages are much more muted than that, even if wages are measured correctly (BOZIO et al., 2015). The wage of one occupation relative to another doesn't change by 90 percent or hundreds of percent. That just does not happen. An obvious explanation is that the supply of labour to occupations is very elastic. So when there is a demand shock in the form of a shift towards demanding certain occupations and not others, this shows up much more in the quantities, in the shares of employment, than it does in relative wages. Thus, it is wrong to think of the supply of labour to occupations as being inelastic. People can choose the occupations to go into, especially in the longer run. They tend not to go into occupations that are declining. So it is wrong to think that someone is fixed as a particular sort of worker in a very narrowly defined occupation, particularly in lower skilled occupations.

We can find some evidence of a positive but weak relationship between wage changes and employment changes over long periods of time. When we regress the change in log-wages in each occupation against the change in log-employment with the US Occupational Employment Survey Data from 1980 to 2012, we find a positive relationship between these two things (Figure 1). However, the coefficient is really tiny, 0.05 , and not significantly different from zero. If we suppose that this relationship is estimating a supply curve of labour to different occupations, that suggests that shifts in demand are going to show up almost entirely in the quantity space. They are not going to show up in the wage space too. So the implication of polarization for wage inequalities is not that big.

What does polarization mean for individuals? Looking only at the aggregate measures of inequality doesn't necessarily tell us what happens to individuals. Examining how individuals experience this process is a very important issue to better 
FIGURE 1 - The Long-Run Relationship between Changes in Wages and Employment, US 1980-2012

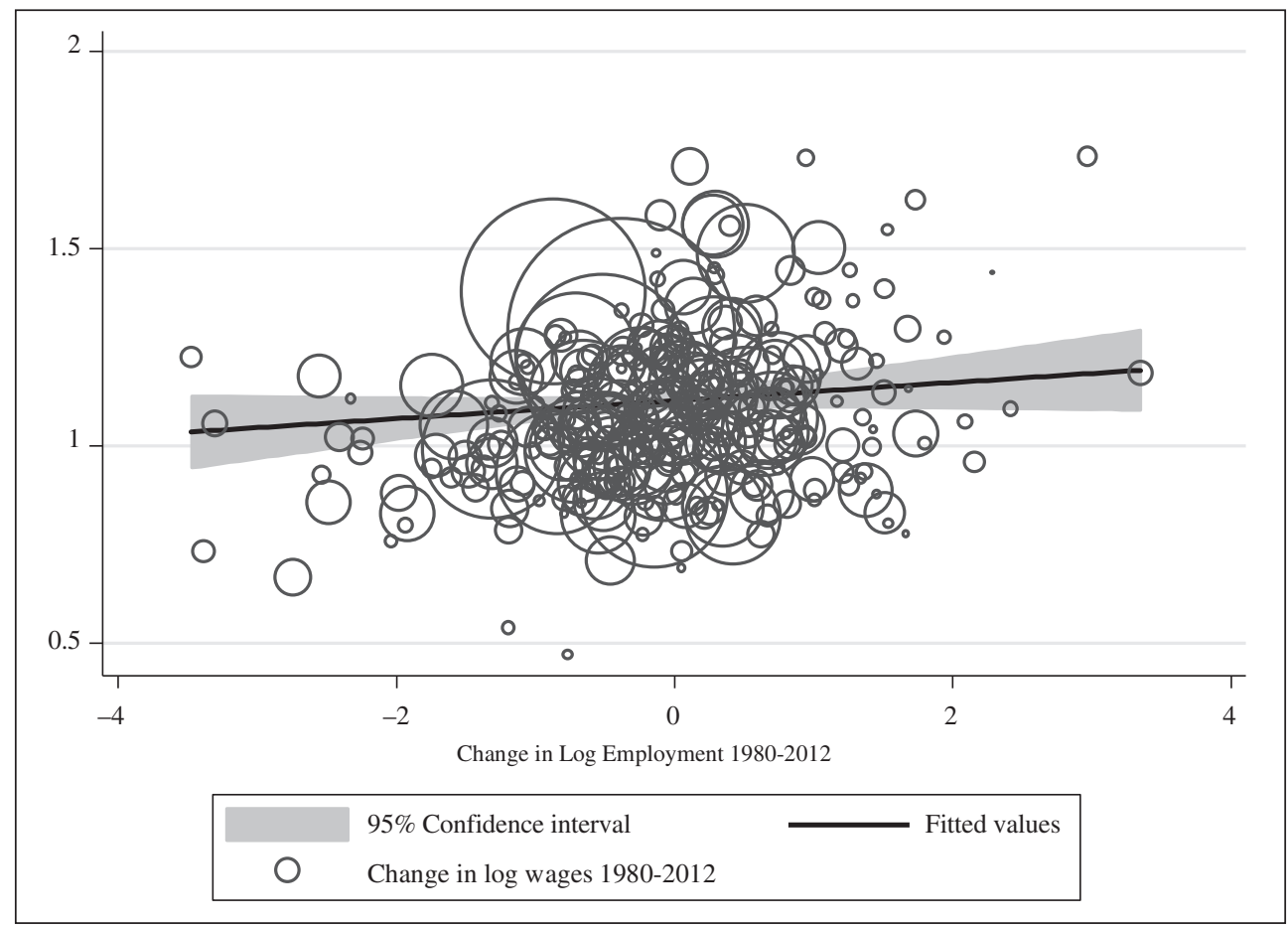

Source: US Occupational Employment Survey, author's calculations.

assess the consequences of polarization on inequalities. There are groups for whom we think that the impact of technology may be particularly bad. These tend to be older workers with specific skills that were once scarce or earned them good money, but now replaced by technology. Those are very clearly identifiable losers. In the past and now, one can give examples of those kinds of people (CORTES et al., 2017). But it is important to understand that there is a lot of fluidity across occupations. In particular the gross flows of people into and out of occupations are much bigger than the net flow. We see people moving from declining occupations to growing occupations, people moving in the other direction. So we don't actually need very big changes in those flows in order to reallocate labour quite a lot. In the UK, for example, 20 percent of workers are changing their jobs every year. The biggest measures of the impact of automation say that might go up to 22 percent. This change is not really a dramatic change in the nature of the labour market and occupations may decline more by lower entry of labour market entrants than higher exit by older workers. In many cases, occupations decline primarily because people stop going into those occupations and, for the individuals already in those occupations, this is a gentle decline rather than anything more abrupt.

This evidence suggests that polarization may have relatively small implications for wage inequality but much larger implications for the structure of employment. 


\section{Polarization: a Global Phenomenon}

A number of papers talk about polarization and globalisation (see eg. HARRIGAN et al. [2016], Heyman [2016], Keller, Utar [2016], Malgouyres [2017]). The underlying question is: how much of the polarization as experienced in high-income countries is really the movement of some jobs to low and middle income countries? If this is happening, what one would expect to find on employment shares in those countries would be the mirror image of what is happening in the high-income countries. Middling jobs would become more important in low and middle-income countries, as they are shifted from countries like France or the UK to those countries. Twenty years ago, there were similar arguments about trade or technology. However, there are not many studies on the changing occupational structure of employment in countries other than high-income countries. So it is difficult to claim that this is what is happening.

On the contrary, some studies suggest polarization is happening in many countries. Figure 2 is taken from an International Labour Organization (ILO) briefing paper (ILO, 2018). It looks at what has been happening to job polarization around the world in countries with different levels of economic development. In all of them, the most negative is in medium-skilled jobs. Figures vary a bit according to whether they have got a lot of high skilled employment growth or low skilled employment growth. From a more general point of view, it looks like polarization is happening in every sort of country. This fact suggests that it is not just the relocation of some jobs from high-income countries to other countries. However, it is not sufficient as a proof, and we need more research on that point. This question should then be put forward on the research agenda.

\section{FIGURE 2 - Job Polarization around the Globe}

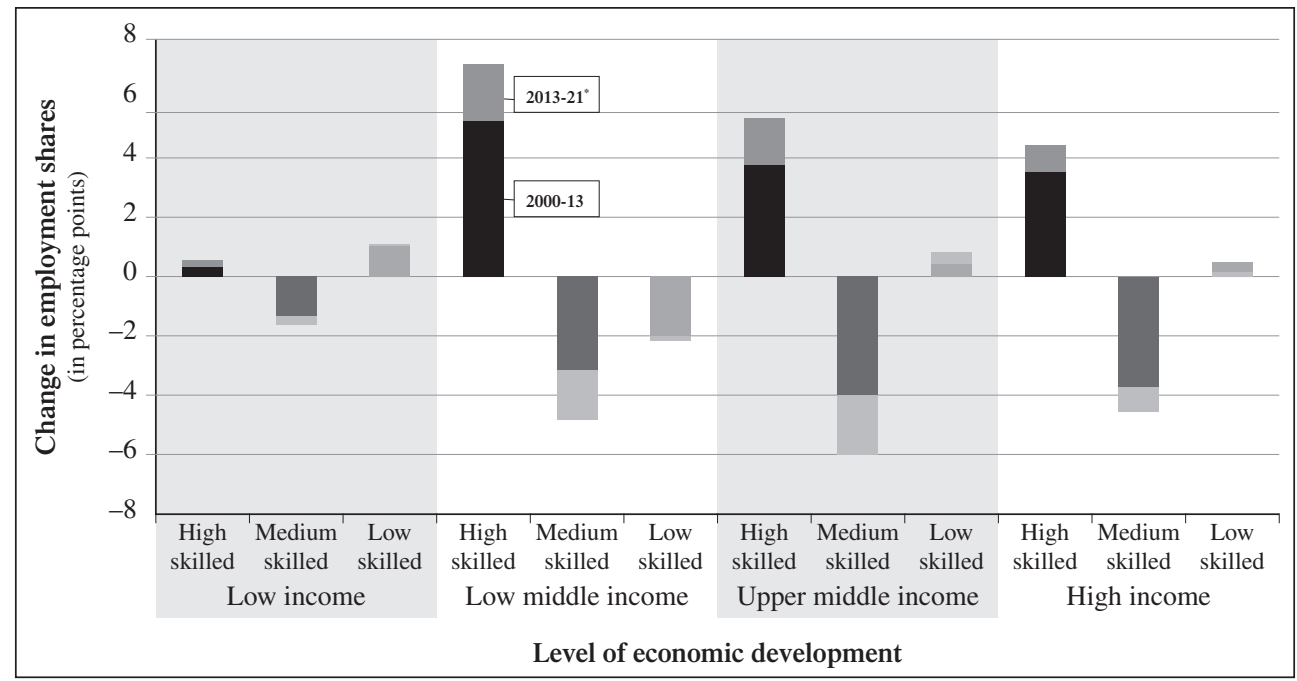

Note: Change in employment shares, in percentage points. * Forecasts after 2016.

Source: International Labour Organisation, ILO Trends Econometric Models, November 2016. 


\section{General Equilibrium Assessments of Polarization}

Finally, I will discuss polarization in a general equilibrium framework. Most of the empirical studies tend to compare outcomes across occupations, sectors or firms that are more or less affected by routinisation or globalisation. Those studies are incredibly useful, but by their nature they cannot say anything about what the aggregate effect of these changes is. The aggregate effect is often subsumed into some general time effect.

What do simple economic models predict about the consequence of new technology? Obviously, there is a very long history of fears about the impact of new technology. Let us put those fears into three groups going from the most extreme to the least extreme. The most extreme is: "new technology means the end of work, it is going to be awful for all workers". Then there is the intermediate one: "some workers might gain but it's generally going to be bad for workers and good for capitalists". And the mildest version is: "new technology might have some distributional consequences among workers, so some will gain, some will lose, but overall we don't really know whether it's going to be good or bad for them".

\section{Polarization from a Consumer's Perspective}

Past predictions about the impact of new technology have always been wrong. Although there have often been groups of workers who have been losers, technology has been the source of the rise in living standards for everyone. Basically, in our societies today there is nobody who is worse off than the equivalent person would have been 200 years ago. That is almost entirely because of new technology. It is interesting to understand where people's past predictions went wrong. One reason is that they focused almost exclusively on a worker's perspective and exclusively on jobs where humans were going to be displaced by new technology. Those are the sort of losers who are often concentrated and visible. But these analyses often missed the gainers. One way of thinking about the gainers is to think about the impact of new technology not from the perspective of a worker but from the perspective of a consumer.

From a consumer's perspective the impact of new technology is the following. Firms are adopting new technology because it lowers costs. If the markets are reasonably competitive, lower costs lead to lower prices. From a consumer's perspective, one can buy everything he/she did before, and one has some income left over. What is he/she going to do with that leftover income? He/she is going to go out and spend it on all sorts of stuff. Doing so, he/she creates jobs for all sorts of people. Once we have that perspective in mind, we can talk about new technology raising the demand for labour. It is also important to understand that it is not just new types of jobs that are created. These are going to be jobs in areas where consumers want to spend their money which is pretty much everything, leading mostly to just more old jobs.

Much the same argument applies to the impact of China. China has made stuff cheaper, that is why there has been import penetration. That has given Western 
consumers more purchasing power. They have gone out and spent that money, and in doing so have created jobs. The worrying point in many current discussions of the impact of new technology is that they make exactly that same mistake of focusing on one narrow perspective and ignoring all the other effects. Nevertheless, it is hard to assess what those aggregate effects are going to be, and that is where general equilibrium models can be useful.

\section{Polarization in a General Equilibrium Framework}

What follows is a very simple model coming from CASELLI, MANNING (2019). Consider a production function $F(L, K, \theta)$ in which output is produced by labour $L$, capital $K$ and technology $\theta$. Let us assume constant returns to scale, perfect competition, one type of labour, one capital good. Let us also assume that the labour supply is inelastic. So, any effect on the demand for labour must go into wages. If one relaxes that hypothesis it would go into employment as well. Consider this as a useful starting point.

Improvements in technology -higher $\theta$ - means more output given input. It gives:

$$
\frac{\partial F}{\partial \theta}>0 .
$$

Nobody would disagree with that, but it is possible that new technology reduces the marginal product of labour:

$$
\frac{\partial^{2} F}{\partial L \partial \theta}<0 .
$$

This situation is what people worry about. There is a lot of discussion about whether new technology is a substitute or complement for labour. Is it capital augmenting or labour augmenting? The reason people think that matters is that in a competitive market, workers will earn their marginal product so that:

$$
W=\frac{\partial F(L, K, \theta)}{\partial L}>0 .
$$

The impact of new technology on wages depends upon whether the marginal product goes up or down with new technology. With fixed capital we get the result that wage could fall with new technology:

$$
\frac{\partial W}{\partial \theta}=\frac{\partial^{2} F(L, K, \theta)}{\partial L \partial \theta}
$$

The problem with this argument is that it assumes that capital is fixed, and one cannot assume that capital is fixed. What happens if you assume that capital is variable? Assume there is a perfectly elastic supply of capital, which is perhaps reasonable as capital goods in the longer-run are all produced. There is no natural limit to the amount of capital in the same way as there is a natural limit to the number of workers. If the cost of capital is $P^{K}(r+\delta)$ made up with a relative price of capital goods $P^{K}$, the interest rate $r$ and the depreciation rate $\delta$, we know that profit maximization means 
the firm will employ capital up to the point where marginal product of capital is equal to the cost of capital:

$$
\frac{\partial F(L, K, \theta)}{\partial K}=P^{K}(r+\delta) .
$$

What happens to wages when we improve new technology and supply of capital is elastic? Let us assume again constant returns to scale and perfect competition. Then payments to labour must be total output minus payments to capital:

$$
W L=F(L, K, \theta)-P^{K}(r+\delta) K .
$$

Differentiating that with respect to $\theta$, gives the results that are taking account of the endogeneity of capital in the long run. We get the following expression:

$$
L \frac{\partial W}{\partial \theta}=\frac{\partial F(L, K, \theta)}{\partial \theta}+\left[\frac{\partial F(L, K, \theta)}{\partial K}-P^{K}(r+\delta)\right] \frac{\partial K}{\partial \theta}-\frac{\partial P^{K}(r+\delta)}{\partial \theta} K .
$$

Looking at the first term, there is a positive effect which just comes from the fact that new technology leads to more output. Then there is the second effect which is about how capital changes. But that is multiplied by the difference between the marginal product of capital and the cost of capital. This difference is zero in the long run, so, that term just disappears. The third term is about how new technology alters the relative cost of capital relative to consumer goods. If the cost of capital goods relative to consumer goods does not rise, this term is positive. So, new technology of any form, whether it is a substitute or a complement to labour, whether it is labour augmenting or capital augmenting, does not matter. The prediction is that wages must go up. The intuition is that new technology leads to more output being produced, and there must be some gainers from it. It cannot be new capital that is being accumulated, because that is paid its marginal product. It just gets what it adds. It cannot also be old capital unless the relative price of capital goods rises.

If the relative price of capital goods does not rise, the only people left over to be gainers are workers. In the long-run labour is the fixed factor of production and all the gains from new technology have to go to the fixed factor. Everything else is produced. There is no particular reason that the rate of return on robots should be any higher than any other form of capital.

So, how can you get the opposite kind of result? There are a number of possibilities. Let us concentrate on imperfect competition. If new technology reduces competition, that can lead to falling wages. Similarly, if there is a rising cost of capital, which might be the case if investment is weak and the rate of return to capital rises, that can be to the disadvantage of workers. In this case, the problem is that the economy is under-investing in robots and new technology, and so the rate of return to investment is going up rather than that it is over-investing.

This framework may seem too simple. What about lots of types of goods and lots of types of workers? Let us try to be as general as possible. Assume any number 
of types of labour, although all in fixed supply, any number of types of goods -consumption, intermediate, investment goods. We also assume that new technology can affect production possibilities in any way whatsoever, in any sector, except that it must always weakly increase output. We assume there are constant returns to scale in all sectors and perfect competition.

Let us compare wages in steady state in two economies with different levels of technology. First, we show that it is impossible for new technology to make all types of workers worse off. One just cannot write down any model of that form which will make all workers worse off. But that might mean the gainers might be a tiny group -it might be one worker. What about the average worker? The second result is that if the price of investment goods relative to consumption goods falls, then new technology must raise the average wage of workers. Again, one cannot write it down any differently. It is the same intuition as before: someone is going to gain from new technology, new capital gets its marginal product, and if the relative price of investment goods is falling, old capital is losing out from this technological change, not gaining.

The only people left over are workers. It does not mean that the labour share of total income necessarily goes up. This is about real wages, not the share of income, and there might be severe distributional effects. But it is very clear that the relative price of investment goods has been falling for decades (Figure 3). There is no doubt about whether that condition holds or not.

A final result is that if the supply of labour of different types in different occupations is perfectly elastic, then workers of all types must gain from technological progress. Intuition then is that relative wages are fixed by that assumption. So, it is as if we would have only one type of worker. If there is one type of worker, that worker has

\section{FIGURE 3 - Relative Price of Investment Goods, US 1947-2016}

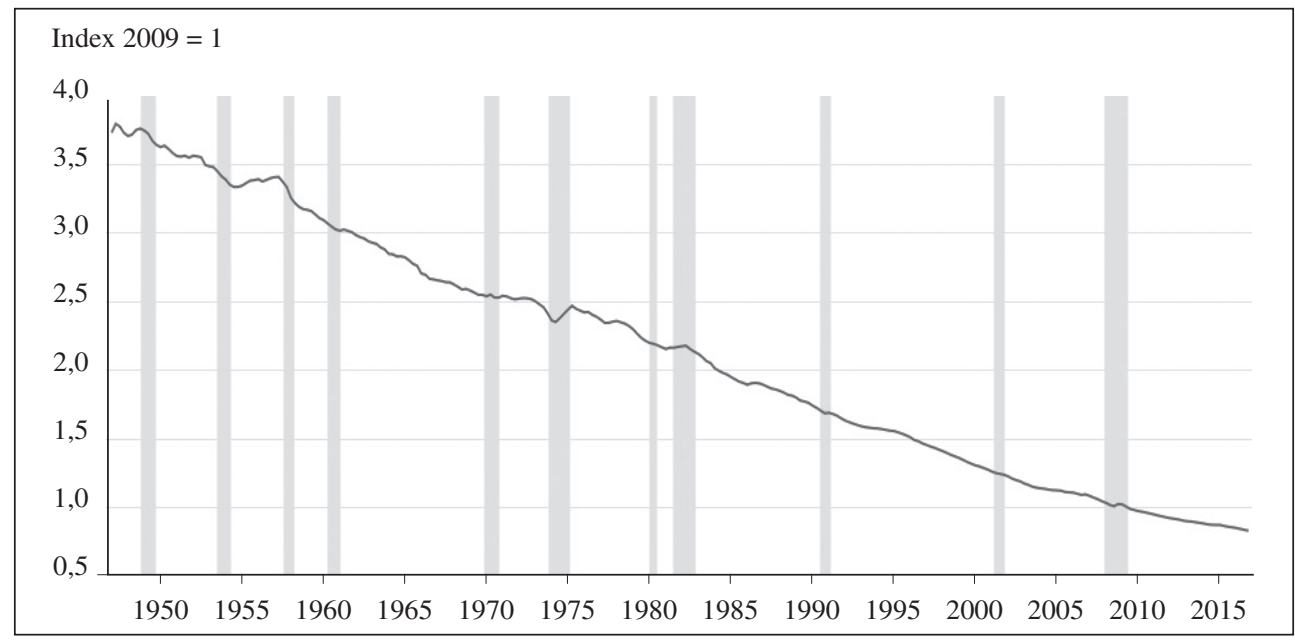

Note: Shaded areas indicate US recessions.

Source: DiCecio, Riccardo, Relative Price of Investment Goods [PIRIC], retrieved from FRED, Federal Reserve Bank of St. Louis; https://fred.stlouisfed.org/series/PIRIC, accessed May 29, 2019. For further details, Di CECIO (2009). 
to gain from new technology. I think that this is not a bad description of what happened in the past in the long-run, and what it suggests is that there are quite powerful forces causing new technology to transmit into higher wages. It also does not depend on the nature of new technology. It just depends on labour ultimately being the fixed factor, everything else being produced.

This text has expressed the view that polarization is mostly a continuation of past changes rather than something radically new, that it has often not had big implications for inequality because of relatively easy mobility across occupations. And that there are reasons why new technology, of any form, is likely to lead to higher wages for most workers.

This paper may seem very complacent about what the implications of technological change are. However, we do need to have public intervention in order to deliver inclusive growth. There are two parts of inclusive growth. First, there is the growth part of it and that has proved particularly difficult for the last decade, but we do know that growth at the frontier is driven by increases in knowledge. We also know that knowledge is a public good: what someone knows does not stop others knowing the same thing. And we know that market economies do not deliver efficient levels of public goods. In this sense, there is no presumption at all, even on the most narrowly conventional economics that a "laisser faire" economy will deliver the efficient level of growth. Although there is some attention people pay to growth promoting policies, it is not perhaps as central as it should be given the importance of growth. The second part to worry about is the inclusive part of growth. We have a set of tools already to use, such as minimum wages, training and redistributing taxation (LORDAN [2018], Keller, UtAR [2016], Bozio et al. [2015]). We need to use them. And we do not need a new set of tools in order to deal with the challenges we face at the moment. We just have to be prepared to use the ones that we have got.

\section{REFERENCES}

Autor, D. H. (2010). The Polarization of Job Opportunities in the US Labor Market: Implications for Employment and Earnings. Washington, DC: Center for American Progress, The Hamilton Project.

Autor, D. H., Dorn, D. (2013). “The Growth of Low-Skill Service Jobs and the Polarization of the US Labor Market.” American Economic Review, 103(5), 1553-1597. http://doi.org/10.1257/ aer.103.5.1553.

Autor, D. H., KatZ, L. F., Kearney, M. S. (2006). "The Polarization of the U.S. Labor Market." American Economic Review, 96(2), 189-194. http://doi.org/10.1257/000282806777212620. 
BÁRÁny, Z. L., Siegel, C. (2018). “Job Polarization and Structural Change.” American Economic Journal: Macroeconomics, 10(1), 57-89. https://doi.org/10.1257/mac.20150258.

Bozio, A., Breda, T., Guillot, M. (2015). Taxes and Technological Determinants of Wage Inequalities: France 1976-2010. Working Paper, no 2015-05, Paris: Paris School of Economics.

Caselli, F., Manning, A. (2019). “Robot Arithmetic: New Technology and Wages.” American Economic Review: Insights, 1(1), 1-12. https://doi.org/10.1257/aeri.20170036.

Cortes, G. M., Jaimovich, N., Siu, H. E. (2017). "Disappearing Routine Jobs: Who, How, and Why?" Journal of Monetary Economics, vol. 91, 69-87. https://doi.org/10.1016/j. jmoneco.2017.09.006.

DiCecio, R. (2009). "Sticky Wages and Sectoral Labor Comovement." Journal of Economic Dynamics and Control, 33(3), 538-553. https://doi.org/10.1016/j.jedc.2008.08.003.

ForD, M. R. (2015). Rise of the Robots: Technology and the Threat of a Jobless Future. New York: Basic Books.

Frey, C. B., Osborne, M. A. (2017). "The Future of Employment: How Susceptible Are Jobs to Computerisation?" Technological Forecasting and Social Change, vol. 114, 254-280. https://doi.org/10.1016/j.techfore.2016.08.019.

Goos, M., Manning, A., Salomons, A. (2009). "Job Polarization in Europe." American Economic Review, 99(2), 58-63. http://doi.org/10.1257/aer.99.2.58.

Harrigan, J., Resheff, A., Toubal, F. (2016). The March of the Techies: Technology, Trade, and Job Polarization in France, 1994-2007. NBER Working Paper, no 22110.

Heyman, F. (2016). "Job Polarization, Job Tasks and the Role of Firms.” Economics Letters, vol. 145.

ILO (2018). The Impact of Technology on the Quality and Quantity of Jobs. Issue Brief, no 6 (Issue brief prepared for the 2nd Meeting of the Global Commission on the Future of Work 15-17 February 2018). Online https://www.ilo.org/wcmsp5/groups/public/---dgreports/---cabinet/documents/publication/wcms_618168.pdf (accessed 13 June 2019).

Keller, W., UtAR, H. (2016). International Trade and Job Polarization: Evidence at the Worker Level. NBER Working Paper, no 22315.

Lordan, G., Neumark, D. (2018). "People Versus Machines: The Impact of Minimum Wages on Automatable Jobs.” Labour Economics, vol. 52, 40-53. https://doi.org/10.1016/j. labeco.2018.03.006.

MALGOUYRES, C. (2017). "The Impact of Chinese Import Competition on the Local Structure of Employment and Wages: Evidence from France." Journal of Regional Science, 57(3), 411-441. 